\title{
A Valuable Option for the Treatment of Respiratory Diseases: Review on the Clinical Evidence of the Ivy Leaves Dry Extract EA $575^{\circledR *}$
}

Authors

Affiliation
Christopher Lang, Patricia Röttger-Lüer, Christiane Staiger

Engelhard Arzneimittel GmbH \& Co. KG, Niederdorfelden, Germany

Key words
Hedera helix
Araliaceae
ivy
clinical trial
non-interventional study
efficacy
safety

received January 12,2015 revised February 16, 2015 accepted February 28, 2015

Bibliography

Dol http://dx.doi.org/

10.1055/s-0035-1545879

Published online April 15, 2015

Planta Med 2015; 81: 968-974

(c) Georg Thieme Verlag KC

Stuttgart · New York .

ISSN 0032-0943

Correspondence

Dr. Christopher Lang

Engelhard Arzneimittel GmbH \&

Co. KG

Herzbergstr. 3

61138 Niederdorfelden

Germany

Phone: + 496101539336

Fax: + 496101539561336

c.lang@engelhard.de

\section{Abstract \\ $\nabla$}

Preparations from ivy leaves (Hederae helicis folium, Hedera helix) dry extracts are well established in the treatment of different respiratory diseases. Until today, the efficacy and safety of ivy leaf preparations has been demonstrated in a variety of controlled clinical studies and non-interventional studies. These results were nearly exclusively obtained using the commercial ivy

\section{Introduction}

$\nabla$

Due to their broncholytic and secretolytic efficacy, preparations from ivy leaves (Hederae helicis folium, Hedera helix L., Araliaceae) are well established in the treatment of productive cough and may also be used for the adjuvant therapy of inflammatory bronchial diseases [1-3]. Among the different ingredients of ivy leaves, such as flavonoids, phenyl carboxylic acids, or essential oil, saponines are primarily responsible for these therapeutic effects [4-8]. In particular, the monodesmosidic $\alpha$-hederin, which arises from the bidesmosidic hederacoside $\mathrm{C}$, was discovered to mediate both secretolysis and bronchodilation by preventing the internalization of $\beta 2$-adrenergic receptors on the surface of bronchial smooth muscle cells and alveolar type II cells. As a consequence, a higher number of $\beta 2$-adrenergic receptors can be activated by the endogenous ligand adrenaline. The $\beta 2$-adrenergic receptor binding and the formation of cAMP is increased. This results in an increased bronchodilation and secretion of surfactant [9-13]. Thus, H. helix represents a rare example of a pharmaceutically used plant

* Dedicated to Professor Dr. Dr. h.c. mult. Adolf Nahrstedt on the occasion of his 75th birthday. leaves dry extract EA $575^{\circledR}$. This paper will provide information on the clinical data obtained with this special extract, showing the importance of those preparations as a valuable therapeutic option for the treatment of acute and chronic respiratory diseases. Overall, 18 publications covering clinical trials and non-interventional studies of, in total, 65383 patients suffering from acute as well as chronic respiratory diseases were included. with a clarified mechanism of action for one of its ingredients.

In order to guarantee a safe and potent herbal extract with a high yield of active ingredients, it is crucial to find and use optimized production parameters. Furthermore, herbal extracts that were obtained by procedures using different conditions might differ in their composition of the ingredients and, thus, in their therapeutic efficacy, potency, and safety $[14,15]$. As a consequence, clinical data obtained by using different ivy leaf extracts cannot be transferred to each other. As shown in a huge number of clinical trials and observational studies, ivy leaf preparations containing the extract EA 575 ${ }^{\circledR}$ [DER 5-7.5: 1, extraction solvent: ethanol $30 \%(\mathrm{~m} / \mathrm{m})$ ] combine this therapeutic efficacy and excellent tolerability due to a patented extraction procedure. This review will summarize the results of studies all using preparations of the ivy leaves dry extract EA $575^{\circledR}$ for the treatment of cough and inflammatory bronchial diseases starting from 1990.

As a source for the review, the Engelhard Arzneimittel GmbH \& Co. KG database was searched for all publications covering clinical studies using EA 575 ${ }^{\circledR}$ preparations starting from the year 1990. Overall, 18 publications (6 in English, 11 in German, 1 in Slovenian) covering clinical trials 
Table 1 Summary of controlled clinical trials with ivy leaves extract EA $575^{\circledR}$.

\begin{tabular}{|c|c|c|c|c|c|c|c|c|c|}
\hline Author/year & DF & No./age & Indication & $S$ & 0 & $\mathbf{R}$ & $\mathbf{P}$ & C & DB \\
\hline $\begin{array}{l}\text { Meyer-Wegener } 1993 \\
\text { [18] }\end{array}$ & Drops & $\begin{array}{l}99 \\
25-70 y\end{array}$ & Simple or chronic bronchitis & $\bullet$ & • & - & & $\bullet 1$ & - \\
\hline $\begin{array}{l}\text { Gulyas } 1999 \text { (cited } \\
\text { according to [4]) }\end{array}$ & Syrup & $\begin{array}{l}20 \\
9-15 y\end{array}$ & Chronic obstructive bronchitis & & $\bullet$ & • & & $\cdot 2$ & \\
\hline Maidannik 2003 [19] & Syrup & $\begin{array}{l}72 \\
7 m-15 y\end{array}$ & $\begin{array}{l}\text { Acute inflammatory diseases } \\
\text { of the respiratory tract }\end{array}$ & • & $\bullet$ & • & & $\bullet 1$ & \\
\hline Bolbot 2004 [20] & Syrup & $\begin{array}{l}50 \\
2-10 y\end{array}$ & $\begin{array}{l}\text { Acute bronchitis (obstructive } \\
\text { and non-obstrucitve) }\end{array}$ & • & • & & & $\cdot 2$ & \\
\hline Mansfeld 1998 [21] & Drops & $\begin{array}{l}24 \\
4-12 y\end{array}$ & Bronchial asthma & $\bullet$ & $\bullet$ & • & • & & - \\
\hline Zeil 2014 [22] & Syrup & $\begin{array}{l}30 \\
6-11 y\end{array}$ & Bronchial asthma & • & - & - & • & & • \\
\hline Gulyas 1997 [23] & $\begin{array}{l}\text { Syrup } \\
\text { Drops }\end{array}$ & $\begin{array}{l}25 \\
10-15 y\end{array}$ & $\begin{array}{l}\text { Chronic obstructive pulmo- } \\
\text { nary diseases }\end{array}$ & & $\bullet$ & - & & - & - \\
\hline Mansfeld 1997 [24] & $\begin{array}{l}\text { Drops } \\
\text { Supp. }\end{array}$ & $\begin{array}{l}26 \\
5-11 y\end{array}$ & Bronchial asthma & • & • & - & & • & \\
\hline Unkauf 2000 [25] & Syrup & $\begin{array}{l}52 \\
0-12 y\end{array}$ & Bronchitis & $\bullet$ & & • & & $\cdot 3$ & \\
\hline Cwientzek 2011 [26] & Drops & $\begin{array}{l}590 \\
2-86 y\end{array}$ & Acute bronchitis & $\bullet$ & & - & & $\cdot 4$ & - \\
\hline
\end{tabular}

DF: dosage form; Supp.: suppositories; S: subjective parameters assessed; O: objective parameters assessed; R: randomized; P: placebo-controlled; C: study with comparator; DB: double-blind; Comparators: ${ }^{1}$ ambroxol, ${ }^{2}$ acetylcystein, ${ }^{3}$ Valverde ${ }^{\circledR},{ }^{4} \mathrm{Hedelix}^{\circledR}$

Table 2 Summary of observational trials with ivy leaves extract EA $575^{\circledR}$.

\begin{tabular}{|c|c|c|c|c|c|c|c|}
\hline Author/year & DF & No./age & Indication & $\mathbf{S}$ & 0 & $\mathbf{E}$ & $\mathbf{T}$ \\
\hline Gulyas 1992 [27] & Syrup & $\begin{array}{l}26 \\
4-10 y\end{array}$ & Chronic-obstructive bronchitis & - & - & • & - \\
\hline Lässig 1996 [28] & Syrup & $\begin{array}{l}113 \\
6-15 y\end{array}$ & Recurrent obstructive bronchitis & - & - & - & • \\
\hline Hecker 1999 [29] & $\begin{array}{l}\text { Syrup } \\
\text { Effervescent } \\
\text { Tablet }\end{array}$ & $\begin{array}{l}248 \\
0-79 y\end{array}$ & $\begin{array}{l}\text { Inflammatory and/or obstructive } \\
\text { diseases of the respiratory tract }\end{array}$ & • & & • & • \\
\hline Hecker 2002 [30] & $\begin{array}{l}\text { Effervescent } \\
\text { Tablet }\end{array}$ & $\begin{array}{l}1350 \\
4-98 y\end{array}$ & Chronic bronchitis & - & & - & - \\
\hline Kraft 2004 [31] & Syrup & $\begin{array}{l}52478 \\
0-12 y\end{array}$ & Symptomatic respiratory tract diseases & • & & & - \\
\hline Fazio 2009 [32] & Syrup & $\begin{array}{l}9657 \\
0-98 y\end{array}$ & $\begin{array}{l}\text { Acute or chronic inflammatory bronchial } \\
\text { diseases }\end{array}$ & $\bullet$ & & $\bullet$ & • \\
\hline Stauss-Grabo 2011 [33] & Tablet & $\begin{array}{l}330 \\
11-85 y\end{array}$ & $\begin{array}{l}\text { Colds accompanied by coughing/chronic } \\
\text { inflam. bronchial disease }\end{array}$ & - & & & $\bullet$ \\
\hline Beden 2011 [34] & Syrup & $\begin{array}{l}193 \\
2-14 y\end{array}$ & Acute airway disease & • & & • & • \\
\hline
\end{tabular}

DF: dosage form; S: subjective parameters assessed; O: objective parameters assessed; E: evaluation of efficacy; T: evaluation of tolerability

and non-interventional studies of, in total, 65383 patients suffering from acute as well as chronic respiratory diseases were included ( $\bullet$ Tables 1 and 2 ).

\section{Lung Function Parameters}

$\nabla$

In the following, both spirometric and bodyplethysmographic parameters assessed in the studies will briefly be defined.

\section{Spirometric parameters [16]}

Spirometry is a fast and noninvasive method for the measurement of lung volume and respiratory flow parameters. It is applied for the diagnosis of diminished lung volume or an airway obstruction and its partial or full reversibility. VC (vital capacity): volume of air that is breathed out after complete inspiration. FVC (forced vital capacity): volume that is forcedly exhaled after complete inspiration. $\mathrm{FEV}_{1}$ (forced expiratory volume in 1 second): breathing volume that is forcedly exhaled in the first second after complete inspiration. $\mathrm{MEF}_{\mathrm{X} \%}$ (maximal expiratory flow): maximal expiratory flow when $\mathrm{x} \%$ of the FVC remain. $\mathrm{MEF}_{\mathrm{x} \% \mathrm{x} \%}$ : mean of the expiratory flow during the interval of $\mathrm{x} \%$ to $\mathrm{x} \%$ of the FVC. $\mathrm{PEF}$ (peak flow): peak flow during maximum expiratory effort.

\section{Bodyplethysmographic parameters [17]}

In contrast to spirometry, the degree of airway obstruction in body plethysmography is not assessed indirectly by the measurement of restrictions of the airflow during forced expiration but 
directly by measuring the airway resistance during tidal breathing. The setup of the body plethysmograph allows an objective measurement of the parameters that is less dependent on the patient's cooperativeness and the motivation by the instructor.

RAW (airway resistance): airflow resistance of the respiratory tract during inspiration and expiration. SRAW (specific airway resistance): sRAW = RAW $\times$ ITGV. ITGV (intrathoracic gas volume): volume of air that is present in the lungs at the end of a passive expiration. RV (residual volume): volume of air that is present in the lungs after maximal forced expiration.

\section{Controlled Clinical Studies}

$\nabla$

EA $575^{\circledR}$ ivy extract preparations vs. chemical expectorants with a different mechanism of action

In a randomized, controlled, double-blind study, the effect of Pro$\operatorname{span}^{\circledR}$ drops was examined in 99 adult patients (age $25-70$ years) with simple or chronic bronchitis and compared with an ambroxol tablet preparation [18]. The patients were treated for four weeks either 3-5 times daily with 20 drops of the ivy leaves preparation or 3-5 times daily with an ambroxol $30 \mathrm{mg}$ tablet including parallel administration of the respective placebo formulation (drops or tablets). The assessment was based on spirometric data (VC, $\mathrm{FEV}_{1}, \mathrm{PEF}$ ), auscultatory findings, and subjective parameters (patient's diary). Both, ivy leaves extract drops and ambroxol tablets showed an equivalent therapeutic effect as documented by the improvement of objective and subjective parameters. The results indicate that patients with simple and chronic bronchitis and patients with obstructive chronic bronchitis may benefit from the ivy preparation comparably to the secretolytic therapy with ambroxol [4]. The tolerance of both preparations was good to excellent. The additional bronchospasmolytic effect of the EA $575^{\circledR}$ formulation compared to ambroxol is depicted in a marked difference in the vital capacity in favor of the ivy group at the end of the treatment (mean: $+9.5 \%$ vs. $+1 \%$ ). With respect to subjective parameters, the ivy leaves group did not suffer from dyspnea after four weeks anymore, whereas in the ambroxol group, the number of patients with dyspnea increased. Additionally, the antitussive effect tended to be stronger in the ivy leaves group. This study indicates that the ivy leaves dry extract is not inferior to the synthetic mucolytic ambroxol and, furthermore, exerts broncholytic properties.

In 1999, the effect of an EA $575^{\circledR}$ preparation was compared with acetylcysteine (ACC) in the treatment of 20 inpatients (9-15 years) suffering from chronic obstructive bronchitis (Gulyas et al. 1999, cited according to [4]). The patients were treated for 14-20 days with the ivy leaves preparation $(n=10)$ or ACC $(n=10)$. The assessment of the efficacy of the therapy by measurement of spirometric and body plethysmographic parameters revealed improvement of $\mathrm{VC}, \mathrm{FEV}_{1}, \mathrm{PEF}$, and RAW with marked advantages in favor of the ivy group.

In a similar open and controlled study, the effect of an EA $575^{\circledR}$ containing syrup ( $n=53$ ) and ambroxol syrup ( $n=19)$ was compared in the treatment of 72 children ( 7 months- 15 years) suffering from acute inflammatory diseases of the respiratory tract [19]. The ivy leaves syrup was used in the following dosages: 16 years old ( 1 teaspoon 3 times daily), 7-14 years old ( 2 teaspoons 3 times daily). The treatment was carried out for 7-14 days, depending on the severity of the disease. The assessment of the efficacy was carried out using objective (VC, FVC, FEV 1 , $\mathrm{PEF}, \mathrm{MEF}_{25}, \mathrm{MEF}_{50}$ ) and subjective (patient's diaries) parameters before the beginning and during the medication period. The authors state that after seven days, auscultatory investigations revealed a fast decrease of crepitation only in the ivy group. Both treatments showed comparative results in the reduction of productive cough (after 7 days, $>50 \%$ of the patients were healed; after 14 days: 100\%). After seven days, children suffering from obstructive diseases showed a normalization of the velocity parameters of external respiration only in the ivy group. The potency of the therapy with the ivy leaves extract was rated as "excellent" or "good" in 90\% (physicians) and $87.1 \%$ (patients) of the cases. This study supports the results conducted by Meyer-Wegener et al. [18] and shows that patients with cough/viscous sputum may benefit from the use of an ivy preparation or ambroxol. Furthermore, the study demonstrated a positive influence on symptoms, such as cough, in acute inflammatory diseases. Blood analyses were performed, so the study contributes to safety data of high dosages of ivy leaf preparations in children [4].

In 2004, Prospan ${ }^{\circledR}$ cough syrup was compared with ACC in the treatment of 50 children (2-10 years) suffering from acute bronchitis (obstructive and nonobstructive) in an open and controlled study [20]. The ivy leaves group $(n=25)$ was dosed 3 times daily with $5 \mathrm{~mL}$ (2-6 years) or 3 times daily with $10 \mathrm{~mL}$ (7-10 years). The ACC group $(n=25)$ was dosed 3 times daily with 100 $200 \mathrm{mg}$ (2-6 years) or 3 times daily with $300-400 \mathrm{mg}$ (7-10 years). Both groups were treated for 7-10 days. For evaluation, lung function parameters (FVC, $\mathrm{FEV}_{1}, \mathrm{PEF}, \mathrm{MEF}_{25}, \mathrm{MEF}_{50}, \mathrm{MEF}_{75}$ ) and clinical symptoms were assessed. Both preparations showed equal expectorating action, but patients in the ivy group profited from a statistically significant higher improvement of the lung function parameters compared to the ACC group (e.g., ivy: $\mathrm{FEV}_{1}$ $62 \pm 8.4$ to $129.62 \pm 18.4$; ACC: $\mathrm{FEV}_{1} 63.7 \pm 6.9$ to $88.6 \pm 8.5$, values in \% from normal), showing that the ivy leaves dry extract EA $575^{\circledR}$ exerts an obvious broncholytic action. Additionally, in $96 \%$ of cases, the efficacy (ACC: $79.2 \%$ ) and in $100 \%$ of the cases, the tolerability (ACC: $76 \%$ ) of the ivy leaves preparation was rated at least as "good". The results of the study indicate that the ivy preparation has a benefit for secretolytic therapy in acute bronchitis, concomitant with a disturbance in the formation and transport of viscous expectoration. The comparison suggests that ivy extracts can be therapeutically equivalent or better than ACC in secretolytic therapy and improvement of cough in patients with acute bronchitis [4].

\section{Placebo-controlled studies}

In order to show the effect of ivy leaf preparations on the improvement of ventilatory disorders, the use of ivy leaves dry extract-containing drops in the treatment of 24 children (4-12 years) with bronchial asthma was evaluated in a randomized, double-blind, placebo-controlled, crossover study [21]. Patients were treated 2 times daily with 25 drops containing EA $575^{\circledR}$ or placebo over a period of three days each, interrupted by a washout phase of three to five days. The primary endpoint of the study was the change in RAW in comparison with placebo therapy. Besides RAW, other objective (ITGV, RV, VC, FVC, FEV 1 ) and subjective (intensity of dyspnea, description of cough) parameters were measured. During active therapy, a clinically relevant and statistically significant decrease of the airways resistance $(-0.14 \mathrm{kPa} / \mathrm{l} / \mathrm{s},-23.6 \%, \mathrm{p}=0.0361)$ and $\operatorname{ITGV}(-0.16 \mathrm{l},-10.1 \%$, $\mathrm{p}=0.0007)$ vs. placebo could be observed. Other spirometric parameters showed a clinically significant improvement in the ivy group compared to placebo. Mean increases in $\mathrm{FEV}_{1}$ found after inhalation of a $\beta_{2}$-sympathomimetic, on day 3 of the treatment, 
$3 \mathrm{~h}$ after medication, proved to be no longer relevant after treatment with the active substance (verum: $\mathrm{FEV}_{1} 1.80 \mathrm{l} ; 10 \mathrm{~min}$ after inhalation of 2 times $100 \mu$ f fenoterol $\mathrm{FEV}_{1} 1.83 \mathrm{l}$; placebo: $\mathrm{FEV}_{1}$ $1.67 \mathrm{l} ; 10 \mathrm{~min}$ after inhalation of 2 times $100 \mu \mathrm{g}$ fenoterol $\mathrm{FEV}_{1}$ 1.79l). The authors concluded from this that the bronchodilator effect of dried ivy leaves extract $3 \mathrm{~h}$ after ingestion is more or less comparable to that of an inhalational $\beta_{2}$-sympathomimetic. The result of this study in children with bronchial asthma represents a clinically justified and statistically validated demonstration of the efficacy of the ivy leaves extract.

The effect of Prospan ${ }^{\circledR}$ cough syrup in the add-on treatment of children suffering from partial or uncontrolled mild persistent allergic asthma ( $n=30,6-11$ years) was evaluated in a further double-blind, placebo-controlled, randomized, crossover study [22]. After the children were adjusted to $400 \mu \mathrm{g}$ budesonide equivalent/day at the beginning of the run-in phase, the patients were treated 2 times daily with $5 \mathrm{~mL}$ dried ivy leaves syrup or placebo for 28-30 days each, interrupted by a washout phase of an additional 28-30 days. For evaluation of the therapy, spirometry and body plethysmography (e.g., $\mathrm{FEV}_{1}, \mathrm{MEF}_{75-25}, \mathrm{MEF}_{25}$, VC, RAW) were conducted. Additionally, the patients filled out questionnaires and documented peak flow and asthma symptoms. After the administration of the ivy leaves syrup, a partial improvement of lung function $\left(\mathrm{MEF}_{75-25}\right.$ change in the mean $0.115 \mathrm{l} / \mathrm{s}$, $\mathrm{p}=0.044 ; \mathrm{MEF}_{25}$ change in the mean $0.086 \mathrm{l} / \mathrm{s}, \mathrm{p}=0.041 ; \mathrm{VC}$, change in the mean $0.052 \mathrm{l}, \mathrm{p}=0.044$ ) compared to the placebo was demonstrated. Concerning the primary endpoint of the study $\left(\mathrm{FEV}_{1}\right)$, no significant change was observed, which might be due to the fact that children diagnosed with bronchial asthma often meet the clinical criteria for severe asthma despite having a normal or only slightly decreased $\mathrm{FEV}_{1}$. The authors state that the $\mathrm{MEF}_{75-25}$ might therefore be regarded as the most significant parameter for airway obstruction and concluded that this proof-ofconcept study demonstrates a significant improvement in lung function parameters in children with mild, persistent, uncontrolled asthma by an add-on treatment with the ivy leaves dry extract EA $575^{\circledR}$.

\section{Further comparative studies}

The potency of two different EA $575^{\circledR}$ dosage forms (ethanol-free syrup, 3 times with $5 \mathrm{~mL}$ per day; ethanol-containing drops, 3 times with 20 drops per day) was compared in a randomized, double-blind, crossover study by assessing the lung function of 25 children (age 10-15) with chronic obstructive pulmonary diseases [23]. Lung parameters were measured on days 1, 5, and 10. After 10 days, a clinically relevant and statistically significant improvement of body plethysmographic (RAW, ITGV, SRAW) and spirometric parameters $\left(\mathrm{FEV}_{1}, \mathrm{FVC}, \mathrm{VC}, \mathrm{PEF}\right)$ could be shown in both groups (e.g., RAW after 10 days: $-0.38 \mathrm{mb} / \mathrm{l} / \mathrm{s}$ syrup; $-0.35 \mathrm{mb} / \mathrm{l} / \mathrm{s}$ drops). The results indicate that both ethanol-free syrup and ethanol-containing drops are effective preparations. In order to achieve a comparable effect, alcohol-free preparations should be submitted in approximately 2 -fold higher dose as the respective alcohol-containing preparations.

In a randomized, crossover study, the effect of two different galenical formulations of EA $575^{\circledR}$ were compared in the treatment of children ( $n=26,5-11$ years) suffering from asthma bronchiale [24]. The patients were treated with ivy leaves extract drops ( 2 times with 25 drops per day) or suppositories ( 2 times with 1 per day) for three days each, interrupted by a washout phase of two to four days. Besides spirometric and body plethysmographic $\left(\mathrm{FEV}_{1}, \mathrm{FVC}, \mathrm{RAW}, \mathrm{ITGV}, \mathrm{RV}, \mathrm{SRAW}\right)$ assessment, the patients were asked to document peak flow values and symptoms. Both therapy forms resulted in a clinically relevant and statistically significant improvement in pulmonary function parameters (RAW: $-0.20 \mathrm{kPa} / \mathrm{l} / \mathrm{s}$ drops, $-0.15 \mathrm{kPa} / \mathrm{l} / \mathrm{s}$ sup.; $\mathrm{FEV}_{1}$ : + 0.231 drops, +0.291 sup.; FVC: +0.211 drops, +0.271 sup.). The tolerability of the treatment was rated "very good" by 25 patients. These results support the data obtained by Mansfeld et al. [21] and Zeil et al. [22] and further confirm the positive effect of ivy leaf preparations as a supportive treatment of asthma bronchiale.

In 2000, a preparation containing a different ivy leaves extract (DER: 3-6: 1, 60\% ethanol V/V) was compared with Prospan ${ }^{\circledR}$ syrup in the treatment of 52 children (up to the age of 12) suffering from bronchitis [25] in a randomized multicenter study. The therapy was conducted for ten days, and the efficacy was evaluated by registration of the severity of bronchitis in a visual analogue scale (VAS, done by the physician on days 1 and 10). Besides the VAS score, other parameters such as condition of the patient, symptoms, tolerability, and auscultation were assessed. The severity of bronchitis decreased by at least $50 \%$ in $98 \%$ of the patients. Furthermore, at the end of the study, $26.9 \%$ of the DER: 3-6: 1 and $36.5 \%$ of the DER: 5-7.5: 1 group showed no bronchitis symptoms anymore. The safety of ivy leaf preparations was again confirmed, as no adverse events were observed. The study was carried out unblinded, which complicates the comparison of both preparations. However, the study confirms the efficacy and excellent tolerability of ivy leaf preparations in the treatment of respiratory diseases.

A further study compared the efficacy and tolerability of formulations containing two different ivy leaf extracts (drops, DER: 2.2-2.9:1, 50\% ethanol V/V: propylene glycol 98:2 and EA 575 ${ }^{\circledR}$ drops) in 590 patients (2-86 years) with acute bronchitis [26]. The patients took one of the medications 3 times daily (from 10 years: 24 drops; 4-10 years: 16 drops; $2-4$ years: 12 drops) over a period of seven days. After the admission examination, patients returned for two further examinations (days 4 and 7). The evaluation of efficacy was based on the reduction of the bronchitis severity score (BSS) and the assessment of the global efficacy by the investigators. The tolerability was evaluated by both investigators and patients using a verbal rating scale. Both groups showed a decrease of BSS to a similar extent (6.2-6.3 on day 1 to 1.4-1.6 on day 7) and a comparable rating in global efficacy and tolerability ("better than good" in both cases). Regarding several BSS subscales, a larger improvement could be observed in patients of the Prospan ${ }^{\circledR}$ group. The results of the study confirm the efficacy and tolerability of ivy leaf extracts.

\section{Non-interventional studies}

In a single center clinical test, 26 children (age 4-10 years) suffering from chronic-obstructive bronchitis were treated with EA $575^{\circledR}$-containing syrup ( 4 times with $1-2$ teaspoons per day) for four weeks [27]. The assessment of the efficacy of the therapy was carried out by weekly spirometric tests (e.g., VC, FVC, FEV PEF) and auscultatory findings. Furthermore, the patients were asked to note dyspnea, frequency of coughing attacks, and expectoration in a patient diary. The symptoms alleviated rapidly and were either completely absent or present in an extremely mild form after conclusion of the therapy (e.g., statistically significant reduction of coughing frequency, $\mathrm{p}<0.01$ ). Supporting the alleviation of the subjective parameters, significant improvements in all measured spirometric parameters were already identified after one week and auscultation identified significant differences 
in dry rale between the start and the end of the study. The tolerance of the therapy was assessed as excellent in $92.3 \%$ of cases.

In a multicenter surveillance study, the efficacy and safety of an ivy leaves syrup was investigated in the treatment of 113 children (6-15 years) suffering from recurrent obstructive bronchitis [28]. Over a period of up to 20 days (in some cases up to 30 days), 3 times with $5 \mathrm{~mL}$ syrup were administered daily to $64 \%$ of the children, whereas $32 \%$ got a higher $(20-25 \mathrm{~mL})$ and $4 \%$ a lower (7.5-10 $\mathrm{mL}$ ) daily dose. The evaluation was based on spirometric (FVC, $\mathrm{FEV}_{1}, \mathrm{PEF}, \mathrm{MEF}_{25}, \mathrm{MEF}_{50}$ ) and symptomatic (interview by physicians, patient's diaries) parameters. After the treatment, the lung function of the patients significantly improved (e.g., FEV1: + 0.167 1). Additionally, physicians confirmed a significant decrease in the quantity of cough and rated $85.7 \%$ of the patients as "healed" or "significantly improved". The medication tolerability was rated as "very good" or "good" in $98.2 \%$ of the cases.

The efficacy and tolerability of EA $575^{\circledR}$-containing syrup and effervescent tablets was assessed in two further open comparative multicentrically designed post-marketing observation trials [29]. Altogether 248 patients (0-79 years) suffering from inflammatory and/or obstructive diseases of the respiratory tract were treated with syrup $(7.3 \pm 2.4$ days $)$ or effervescent tablets $(8.2 \pm 2.5$ days). $76 \%$ of the patients were treated following the recommended dosing in the patient information leaflet, $12 \%$ were treated with a higher, and $12 \%$ with a lower dose as recommended. The efficacy of the therapy was assessed by a doctor in a 4-level scale and by the patient judging the improvements of individual symptoms. The evaluation of tolerance resulted from the occurrence of adverse effects and from a general assessment made by the doctor. The efficacy of the therapy was rated as "very good" to "good" by the physicians in $86 \%$ of the cases. With regard to the individual symptoms, cough and expectoration had improved in $90 \%$ of the cases, and dyspnea and respiratory pain disappeared in $60 \%$ of the cases. Besides the excellent efficacy, the therapy tolerability was rated as "very good" to "good" by $98 \%$ of the patients. The results of the study demonstrate that the different dosages of the various administration forms of EA $575^{\circledR}$ established in clinical trials are also valid in wide clinical practice.

EA $575^{\circledR}$-containing effervescent tablets were evaluated regarding their efficacy and tolerability in an additional multicenter post-marketing surveillance study by treating 1350 patients (498 years) suffering from chronic bronchitis [30]. The patients were treated according to the recommended dosing in the patient information leaflet for four weeks. During baseline examination, the symptoms of the bronchial illness and their duration were documented using a standardized questionnaire. At the end of the observational period, the physicians assessed the effectiveness and the tolerability of the treatment. Additionally, the patients were asked to describe any occurring adverse effects. After four weeks, more than $80 \%$ of the patients showed improved symptoms (cough $92.2 \%$, expectoration $94.2 \%$, dyspnea $83.1 \%$, respiratory pain $86.9 \%$ ) and were free of complaints in each of the four symptoms in $38 \%$ of the cases. Only three $(0.2 \%)$ of the patients experienced adverse events in which a causal relationship to the drug under investigation could not be excluded.

The high level of tolerability of the EA $575^{\circledR}$-containing syrup preparation was confirmed in a retrospective survey [31]. In the study, the type and frequency of adverse drug reactions of 52478 children (0-12 years) with symptomatic respiratory tract diseases, who were treated with ivy leaves syrup, were evaluated by the use of structured questionnaires. As a result, adverse drug reactions (ADR) occurred in only $0.22 \%$ (115) of all patients, which were all non-serious, mild, and transient in nature. The incidence of ADR's decreased with increasing age. Furthermore, the most frequently mentioned ADR was diarrhea, which, in most cases, presumably results due to the sorbitol content of the cough syrup. The study provides substantial information on tolerance and safety because it included a large number of patients [4].

The tolerance, safety, and efficacy of $H$. helix extract was evaluated in a prospective post-marketing study with a large patient collective ( $n=9657,0-98$ years, $53.7 \%$ children) suffering from acute or chronic inflammatory bronchial diseases [32]. The patients were treated with ivy leaves syrup ( $0-5$ years: 3 times with $2.5 \mathrm{~mL} ; 6-12$ years: 3 times with $5 \mathrm{~mL} ;>12$ years: 3 times with 5-7.5 mL per day) for seven days. Afterwards, the severity of the symptoms was compared with the initial examination, and the tolerability of the therapy was assessed by the physicians with a semi-closed questionnaire. In $95.1 \%$ of the cases, the symptoms (cough, expectoration, dyspnea, respiratory chest pain) were improved or completely absent. The tolerability of the therapy was rated as "good" or "very good" in $96.6 \%$ of the cases. Adverse events were only reported in a total of $2.1 \%$ of the patients, mostly reported in children mainly as mild or transient gastrointestinal disorders. The additional treatment with antibiotics might contribute to the increased rate of ADR's compared to other studies, as the occurrence of gastrointestinal side effects during therapy with antibiotics is often observed. Therefore, it is most likely that the gastrointestinal side effects are primarily caused by the antibiotic treatment. The study provides substantial information on tolerance and safety because of the large number of patients and the use of relatively high dosages [4].

The tolerability of the ivy leaves dry extract in tablet form was evaluated in a post-marketing surveillance study by the treatment of 330 patients (11-85 years) suffering from colds accompanied by coughing or from chronic inflammatory bronchial diseases [33]. The patients received at least a seven-day treatment with a dose of 3 times 1 to 3 times 2 tablets per day. The tolerability was assessed by both practitioners and patients using questionnaires, whereas the compliance was evaluated only by the physicians. The excellent tolerability of the ivy leaves preparation could again be confirmed, as $98.5 \%$ of the practitioners and $96.4 \%$ of the patients judged the treatment as "very good" or "good" (no serious ADR was reported). Furthermore, the physicians rated the compliance of the tablet formulation as "good" in $99.1 \%$ of the cases.

In a prospective post-marketing study, 193 children (2-14 years) suffering from acute airway disease were treated with a $H$. helix extract-containing syrup [34]. The characteristics of individual symptoms (cough, expectoration, dyspnea, pain associated with cough) were evaluated before and seven days after treatment. The tolerability was documented by evaluation of all undesirable effects. After therapeutic intervention, $93.7 \%$ of the children experienced full or partial improvement of the symptoms (e.g, productive cough: $43.6 \%$ at first visit, $84.9 \%$ after seven days, significantly decreased nocturnal cough and frequency of cough). Furthermore, physicians and patients assessed the treatment of the symptoms with ivy leaves extract to be superior compared to treatment with other therapies in the past. The safety of the therapy with ivy leaf extracts was again confirmed, as $97.9 \%$ of the patients assessed the tolerance as "good" or "very good". 


\section{Conclusion}

\section{$\nabla$}

Since decades, ivy leaves extract preparations have been used for the treatment of coughs, particularly when associated with hypersecretion of viscous mucus and as an adjuvant treatment of inflammatory bronchial diseases $[3,6,35,36]$. Ivy leaves are a very good example of a well established and thoroughly investigated source of a phytopharmaceutical that is highlighted by the rare fact that the mechanism of action was clarified for parts of its active ingredients. Recently, it was shown that $\alpha$-hederin, arising from the main saponine hedercoside $C$, prevents $\beta_{2}$-adrenergic receptors from internalization and enables a higher number of receptors to be activated by the endogenous ligand adrenaline [11]. As a consequence, a higher grade of bronchodilation and surfactant production is achieved, leading to the bronchospasmolytic, secretolytic, expectorant and, in turn, antitussive effect of ivy leaves extract preparations, which were observed in clinical trials. Because of the well-established efficacy and tolerability, ivy leaves are listed in the ESCOP monography and in the positive list of the German Kommission E. Furthermore, the Committee on Herbal Medicinal Products (HMPC) attested certain ivy leaf extracts to fulfill the requirements of a well-established use with recognized efficacy $[4,5]$. Among those, the ivy leaves dry extract EA $575{ }^{\circledR}$ [DER: 5-7.5: 1 , extraction solvent: ethanol 30\% $(\mathrm{m} / \mathrm{m})$ ], produced by a patented procedure, has a special status, as by far the most controlled clinical and post-marketing studies were carried out using this particular extract for treatment. These studies cover the huge number of, overall, more than 65000 patients proving the efficacy and excellent tolerability of herbal medicinal products containing EA $575^{\circledR}$ as the active ingredient. The safety of these products is furthermore underlined by the fact that some of the studies included the application of higher dosages or the treatment of special population groups like children below 1 year of age. Despite the existing data of a very extensive patient collective, clinical research with preparations containing EA $575^{\circledR}$ has been performed further on. This is illustrated by the publication of four new studies $[22,26,33,34]$ since the release of the HMPC assessment report [4]. All of these studies further confirm the so far obtained findings regarding efficacy and safety of the ivy leaves dry extract. Furthermore, the non-inferiority of the ivy leaves extract in the treatment of respiratory tract illnesses compared to synthetic pharmaceuticals like ambroxol $[18,19]$ and acetylcysteine [20] could clearly be shown. Additionally, the patients treated with the ivy leaves extract benefit from the additional bronchospasmolytic effect, which enables the use in the adjuvant therapy of obstructive respiratory diseases like asthma bronchiale $[21,22,24]$. The results obtained for EA $575^{\circledR}$ from the clinical studies mentioned in this review apply exclusively for herbal medicinal products containing this extract, as extracts that are obtained by different procedures represent distinct active ingredients [37].

\section{Conflict of Interest \\ $\nabla$}

Christopher Lang, Patricia Röttger-Lüer, and Christiane Staiger are employees of the Engelhard Arzneimittel GmbH \& Co. KG.

\footnotetext{
References

1 Mayer H, Pfandl A, Grigorieff A, Zickner I. Der Efeu - eine alte Kult- und Heilpflanze. Pharm Ztg 1987; 138: 2673-2676
}

2 Landgrebe H, Matusch R, Runkel F, Hecker M. Wirkung und Anwendung einer Heilpflanze. Pharm Ztg 1999; 144: 11-15

3 Stauss-Grabo M, Atiye S. Efeu - eine traditionelle Heilpflanze in der modernen Phytotherapie. Z Phytother 2009; 30: 289-291

4 The Committee on Herbal Medicinal Products. Assessment report on $\mathrm{He}$ dera helix L., folium. 2011. EMA/HMPC/289432/2009. Available online at http://www.ema.europa.eu/docs/en_GB/document_library/Herbal_-_HMPC_assessment_report/2012/01/WC500120648.pdf. Accessed March 20, 2015

5 The Committee on Herbal Medicinal Products. Community herbal monograph on Hedera helix L., folium. 2011. EMA/HMPC/289430/ 2009. Available online at http://www.ema.europa.eu/docs/en_GB/document_library/Herbal_-_Community_herbal_monograph/2011/04/ WC500105313.pdf. Accessed March 20, 2015

6 ESCOP Monographs. The scientific foundation for herbal medicinal products, 2nd edition. European Scientific Cooperative on Phytotherapy. Hederae helicis folium, ivy leaf. Stuttgart: Thieme Verlag; 2003: 241-247

7 Hiller K, Willuhn G, Loew D. Hederae folium - Efeublätter. In: Wichtl M, editor. Teedrogen und Phytopharmaka. Ein Handbuch für die Praxis auf wissenschaftlicher Grundlage, 5th edition. Stuttgart: Wissenschaftliche Verlagsgesellschaft; 2009: 328-330

8 Trute A, Gross J, Mutschler E, Nahrstedt A. In vitro antispasmodic compounds of the dry extract obtained from Hedera helix. Planta Med 1997; 63: 125-129

9 Hegener O, Prenner L, Runkel F, Baader SL, Kappler J, Häberlein H. Dynamics of $\beta 2$-adrenergic receptor-ligand complexes on living cells. Biochemistry 2004; 43: 6190-6199

10 Runkel F, Prenner L, Häberlein H. In-vitro Studien: Ein Beitrag zum Wirkmechanismus von Efeu. Pharm Ztg 2005; 150: 19-25

11 Sieben A, Prenner L, Sorkalla T, Wolf A, Jakobs D, Runkel F, Häberlein H. $\alpha$ Hederin, but not hederacoside $C$ and hederagenin from Hedera helix, affects the binding behaviour, dynamics, and regulation of $\beta 2$-adrenergic receptors. Biochemistry 2009; 48: 3477-3482

12 Wolf A, Gosens R, Meurs H, Häberlein H. Pre-treatment with $\alpha$-hederin increases $\beta$-adrenoceptor mediated relaxation of airway smooth muscle. Phytomedicine 2011; 18: 214-218

13 Greunke C, Hage-Hülsmann A, Sorkalla T, Keksel N, Häberlein F, Häberlein $H$. A systematic study on the influence of the main ingredients of an ivy leaves dry extract on the $\beta_{2}$-adrenergic responsiveness of human airway smooth muscle cells. Pulm Pharmacol Ther, advance online publication 16 September 2014; doi: DOI: 10.1016/j. pupt.2014.09.002

14 Gaedcke F, Steinhoff B. Phytopharmaka. Stuttgart: Wissenschaftliche Verlagsgesellschaft; 2000

15 Blume H, Brauer KG, Dingermann T, Mutschler E, Steinhilber D, Abdel-Tawab M, Zündorf I. Leitlinie Gute Substitutionspraxis der Deutschen Pharmazeutischen Gesellschaft. Available at http://www.dphg.de/fileadmin/content/pdfs/dphg_leitlinie_gute_substitutionspraxis.pdf. Accessed January 06, 2015

16 Criée CP, Berdel D, Heise D, Kardos P, Köhler D, Leupold W, Magnussen $H$, Marek W, Merget R, Mitfessel H, Rolke M, Sorichter S, Worth H, Wuthe H. Empfehlungen der Deutschen Atemwegsliga zur Spirometrie. Oberhaching: Dustri-Verlag Dr. Karl Feistle; 2006

17 Criée CP, Berdel D, Heise D, Jörres RA, Kardos P, Köhler D, Leupold $W$, Magnussen H, Marek W, Merget R, Mitfessel H, Raschke K, Rolke M, Smith HJ, Sorichter S, Worth H. Empfehlungen zur Ganzkörperplethysmographie (Bodyplethysmographie). Oberhaching: Dustri-Verlag Dr. Karl Feistle; 2009

18 Meyer-Wegener J, Liebscher K, Hettich M, Kastner HG. Efeu versus Ambroxol bei chronischer Bronchitis. Z Allg Med 1993; 69: 61-66

19 Maidannik V, Duka E, Kachalova O, Efanova A, Svoykina S, Sosnovskaja T. Efficacy of Prospan application in children's disease of respiratory tract. Pediatr Tocol Gyn 2003; 4: 1-7

20 Bolbot Y, Prokhorov E, Mokia S, Yurtseva A. Comparing the efficacy and safety of high-concentrate (5-7.5: 1) ivy leaves extract and acetylcysteine for treatment of children with acute bronchitis. Drugs of Ukraine 2004; 11: 1-4

21 Mansfeld HJ, Höhre H, Repges R, Dethlefsen U. Therapy of bronchial asthma with dried ivy leaf extract. Münch Med Wschr 1998; 140: 26-30

22 Zeil S, Schwanebeck $U$, Vogelberg $C$. Tolerance and effect of an add-on treatment with a cough medicine containing ivy leaves dry extract on lung function in children with bronchial asthma. Phytomedicine 2014; 21: $1216-1220$ 
23 Gulyas A, Repges $R$, Dethlefsen $U$. Consequent therapy of chronic obstructive respiratory tract illnesses in children. Atemw Lungenkrkh 1997; 5: 291-294

24 Mansfeld HJ, Höhre H, Repges R, Dethlefsen U. Sekretolyse und Spasmolyse. TW Pädiatrie 1997; 10: 155-157

25 Unkauf M, Friedrich M. Bronchitis bei Kindern - Klinische Studie mit Efeublätter-Trockenextrakt. Der Bayerische Internist 2000; 4: 1-4

26 Cwientzek $U$, Ottillinger B, Arenberger $P$. Acute bronchitis therapy with ivy leaves extracts in a two-arm study. A double-blind, randomized study vs. an other ivy leaves extract. Phytomedicine 2011; 18: 11051109

27 Gulyas A, Lämmlein MM. The treatment of chronic obstructive bronchitis in children. Sozialpädiatrie 1992; 14: 632-634

28 Lässig W, Generlich H, Heydolph F, Paditz E. Wirksamkeit und Verträglichkeit efeuhaltiger Hustenmittel. TW Pädiatrie 1996; 9: 489-491

29 Hecker M. Wirksamkeit und Verträglichkeit von Efeuextrakt bei Patienten mit Atemwegserkrankungen. Natura Med 1999; 14: 28-33

30 Hecker M, Runkel F, Völp A. Behandlung chronischer Bronchitits mit einem Spezialextrakt aus Efeublättern - multizentrische Anwendungsbeobachtung mit 1350 Patienten. Forsch Komplementärmed Klass Naturheilkd 2002; 9: 77-84
31 Kraft K. Verträglichkeit von Efeublättertrockenextrakt im Kindesalter Z Phytother 2004; 25: 179-181

32 Fazio S, Pouso J, Dolinsky D, Fernandez A, Hernandez M, Clavier G, Hecker $M$. Tolerance, safety and efficacy of Hedera helix extract in inflammatory bronchial diseases under clinical practice conditions: a prospective, open, multicenter postmarketing study in 9657 patients. Phytomedicine 2009; 16: 17-24

33 Stauss-Grabo M, Atiye S, Warnke A, Wedemeyer RS, Donath F, Blume HH. Observational study on the tolerability and safety of film-coated tablets containing ivy extract (Prospan ${ }^{\circledR}$ Cough Tablets) in the treatment of colds accompanied by coughing. Phytomedicine 2011; 18: 433-436

34 Beden AB, Perko J, Terčelj R, Kreft S. Treatment of acute respiratory infections in Slovenian children with ivy leaf extract syrup. Zdrav Vestn 2011; 80: 276-284

35 Kraft K, Enzel U. Einsatz von Phytopharmaka bei Kindern. Indikationen, Möglichkeiten, Grenzen. Pädiat Prax 2013; 80: 695-704

36 Hofmann D, Hecker M, Völp A. Efficacy of dry extract of ivy leaves in children with bronchial asthma - a review of randomized controlled trials. Phytomedicine 2003; 10: 213-220

37 Veit M. Gleiche Quelle, gleiche Wirkung? Dtsch Apoth Ztg 2014; 33: 3518-3523 